\title{
Urban parking policy in Europe: a conceptualization of past and possible future trends
}

\section{Authors}

Giuliano Mingardo ${ }^{a}$ (corresponding author), Bert van Wee ${ }^{b}$, Tom Rye ${ }^{c}$

\section{Affiliation:}

a Erasmus School of Economics, Erasmus University Rotterdam, Room H16-09, P.O. Box

1738, NL-3000 DR Rotterdam, the Netherlands; Tel: ++31 10 4082427; Email: mingardo@ese.eur.nl

${ }^{b}$ Transport and Logistics Group, Faculty of Technology, Policy and Management, Delft University of Technology, PO Box 5015, 2600 GA Delft, The Netherlands

${ }^{\mathrm{c}}$ Department of Technology and Society, Lund Institute of Technology, Lund University, Box 118, 22100 Lund, Sweden

\section{Abstract}

In the last two decades parking has increasingly gained importance in urban planning. Despite the growing number of papers published in recent years, an overall conceptualization of parking policy is still missing. Previous attempts (Shoup, 2005; Litman, 2006; and Barter, 2010) focus mainly on the North American planning experience. We try to bridge this gap analysing the evolution of parking policy in Europe. In this paper we first present the key aspects of parking policy, and describe their generic evolution. Next we suggest a new approach for parking policy making. We conclude by discussing some of the major challenges policy makers will face in the near future regarding parking in urban areas.

Keywords: parking; parking policy; conceptualization; key aspects, Europe. 


\section{Introduction}

In the last two decades parking has increasingly gained importance in urban planning mainly because car ownership and use keep growing while urban space becomes scarcer. The literature on parking has been for a long time dominated by grey literature, such as reports and (non scientific) articles published by professionals working in parking. Scientific publications were relatively scarce until the end of the 1990s. In the words of Ison and Rye (2006, p.445) "whilst there are academic papers in the area ... (parking) is, on the whole, an under-researched area of transport" especially when compared to an area such as road user charging. Although in the last few years several papers on parking have been published an overall theory on parking policy is still lacking (Barter, 2010).

The existing literature on parking - both the scientific and the grey one - is very dispersed with most of the articles, papers and reports focussing on specific aspects of parking and/or on specific empirical findings. Additionally, only a few authors have tried to explore the theoretical aspects of parking as a whole. Arnott (2006) researches optimal parking policies in urban areas, whilst others (Verhoef et al., 1995; Calthrop et al., 2000; Button, 2006) focus on the economic analysis of parking policies as a substitute to road pricing. Next, some authors address the theoretical aspect of parking problems in specific areas such as the Central Business District (Ligocki and Zonn, 1984; Voith, 1997 and 1998) or residential areas (Merriman, 1995). Finally Marsden (2006) reviews the (scarce) evidence base upon which parking policies are based concluding that more research is needed in order to fully understand the impact of parking on urban accessibility and attractiveness.

There are very few examples of comprehensive works on parking, the most important being Jakle and Sculle (2004), Litman (2006), and Shoup (2005). Later, Barter (2010) proposed a three-way categorization for parking policy, going further than Litman and Shoup. All of them are mainly based on the North American planning experience. More recently Kodransky and Hermann (2011) have reviewed successful parking policies in European cities. In this paper we describe the development of parking policy in urban areas on the basis of the European parking planning experience of the last decades. More specifically the aim of this paper is twofold:

a) To conceptualize parking policy in Europe, that is, to propose key aspects of parking policy and a generic description of how it evolves;

b) To contribute to the discussion on the future of parking policy in European cities, by proposing a new approach for it. 
To the authors' knowledge this is one of the few attempts to form a comprehensive conceptualisation of urban parking policy. We build on the previous work on Shoup (2005), Litman (2006), Barter (2010) and EU (2005), but go further by introducing a framework to describe the evolution of parking policy. We focus on the European planning experience, with most examples coming from the UK and the Netherlands because these two countries are generally recognized as some of the most experienced in Europe in terms of parking policy and management.

The methodology used for this paper is inspired by grounded theory, a well-known research methodology in the social science. This method is used to generate theories from both inductive and deductive thinking (Glaser, 1992). We do not claim to fully have applied grounded theory in all its steps, but adopted it as a way of developing a new theory. More specifically we first generated concepts regarding parking policy based on the scientific and the grey literature and on the authors' own working experience. Next we discussed our ideas with several experts and academics in the field, mainly but not exclusively from the UK and Netherlands, and modified it if needed. After around ten such discussions, our theory building reached a relative saturation point; further discussions did not contribute further to theoretical development. Despite the fact that most information presented in the paper is based on the UK and Dutch planning experience, we believe that the conclusions and policy implications are likely to hold for other European cities as well. This is supported by previous research which suggests that European cities follow a similar pattern in parking policy (EU, 2005; Dijk, 2010) and confirmed by the discussions with experts.

The remainder of this paper is organized as follows. In section two we present the conceptual elements of parking policy, while in section three we propose a framework that explains how urban parking policy evolves. Section four suggests a different approach for parking policy. We conclude by discussing some of major challenges that will characterize the future of urban parking and making suggestions for further research. 


\section{A conceptualization of parking policies}

In most European countries parking policy is a local policy. Each city and town is usually free to set the objectives of the policy and to select the policy instruments to implement it. National governments usually provide guidelines, mostly on parking requirements (see section 2.1.1), but rarely interfere in policy making ${ }^{1}$. The main reason for this is the recognition that parking is a local matter and that local authorities will deal with it better than will regional or national government.

In this section we conceptualize parking policies distinguishing three aspects: a) the key elements of parking supply; b) the policy instruments that can be used to change those elements; c) the aims of policy making, or the effects that parking policies should have.

\subsection{Key elements and policy instruments}

The key elements of parking supply include:

- The number of parking places by type (i.e. on- and off-street parking);

- The location of parking places by type (e.g. out-of-town Park and Ride facilities, downtown garages ...);

Parking supply is of course mediated depending on who owns and controls it. On-street parking is almost totally owned and mostly controlled by local authorities; off-street parking might be owned by either local authorities or private parties and it's usually controlled either by the local authority or by a private parking operator.

Key policy instruments basically consist of:

- Parking requirements, i.e. the "number of parking spaces that must be supplied at a particular location, which is often mandated in zoning codes or development requirements based on publish standards" (Litman, 2006; p. 272).

- Parking regulations, which typically include free parking, time restrictions, users' restrictions (e.g. parking only for residents, or disabled, or public transport passengers ...) and pricing parking.

- Marketing, i.e. trying to persuade car users to use specific parking locations, such as campaigns to use $\mathrm{P} \& \mathrm{R}$ facilities, or specific payment methods such as paying by mobile phone.

- Information and communication, such as (dynamic) route guidance to (available) parking places, either at the road side (information) or via satnav system (communication).

\footnotetext{
${ }^{1}$ An exception to this is for example Poland, where the national government has the authority to decide the maximum price for on-street parking tariffs.
} 
Parking requirements and regulations are policy instruments that are directly used to influence the key elements of parking supply. Marketing and communication are instruments that do have an impact on parking behaviour but not directly on the two elements presented above.

In addition other policies can also have an impact on parking practice, land-use planning being an example. E.g. the type of houses built can have an impact on parking elements, firstly because specific houses attract specific income groups, and secondly because of possibilities to park cars on own territory. We limit our analysis to the abovementioned key policy instruments only.

\subsubsection{Parking requirements}

Parking requirements are also known as parking standards or parking norms. Shoup (1999 and 2005) and Litman (2006) have largely discussed the problems related to parking requirements, the most important being the fact that "... urban planners neglect both the price and the cost of parking when they set parking requirements, and the maximum observed parking demand becomes the minimum required parking supply" (Shoup, 2005: p. 580). Parking standards can be set up by national or local authorities. For example in the Netherlands the parking requirements used by municipalities are usually based on the official standards published by the Platform for transport, infrastructure and public space (CROW, 2012). Parking standards can be used by local authorities as minimum or as maximum. Minimum parking standards are usually used when the local authority wants the project developer of a location to provide enough parking capacity in order to satisfy the demand generated from that specific location. The objective is to prevent that a (new) location, for example an office building, generates parking problems in its vicinity, for example residential areas. On the other side, maximum standards are mostly used in central areas, usually well served by public transport, and are meant to restrict the number of motorists entering the location. In the UK parking standards are set by local authorities. In London the change from minimum to maximum standards first took place in the central area with the Greater London Development Plan in 1976 (Lester, 2013). The 2004 parking reform extended this change for the whole city. Guo and Ren (2013) found that this reform considerably reduced parking supply in residential areas. As suggested by the authors, the London reform was mainly promoted by national guidance: the Planning Policy Guidelines 13 - Transport (DCLG, 2001a) and the Planning Policy Guidelines 3- Housing (DCLG, 2001b).

\subsubsection{Parking regulations}

Parking regulations are defined as "regulations that control who, when, and how long vehicles may park at a particular location in order to prioritize parking facility use" (Litman, 2006; p. 272) 
and can be considered as the very heart of parking policy ${ }^{2}$. They typically include time restrictions, users' restrictions - e.g. parking only for residents or for disabled - and pricing parking. The latter is probably the most powerful and, from a political point of view, controversial tool of parking policy.

In Europe parking regulations have a relatively long history. In the Netherlands pricing parking was introduced in the 60's and, since then, has been continuously expanding. In the UK the first parking meters were introduced in London in $1958^{3}$ and again on-street parking controls have been continuously increased since then, but with a particular boost after 1991, when local authorities became able to take over parking enforcement from the police; and also between 1999 and 2011 in England when the then Labour government's wider local transport policy encouraged many local authorities to revisit and strengthen their on- and off-street parking policies and measures.

The underpinnings of parking regulations generally come from economic (welfare) theory. As suggested by Glazer and Niskanen (1992) parking has the characteristics of a private good. It is excludable - it is possible to prevent a class of consumers from consuming parking - and it is rival - only one motorist can use a specific parking space at a specific time. For these reasons economic theory suggests that marginal cost pricing should be applied to parking. Accordingly, the parking fee should equal the marginal cost of providing that specific parking place. Additionally, parking needs space, which is not available for other (urban) functions. Space is a scarce resource and, accordingly, the use of it should be charged. However, the practice shows a quite different picture. Hardly any city applies parking fees that reflect the costs of providing parking (van Ommeren et al, 2011). Several authors have recognized that one of the main sources of inefficiency in urban transport markets is the fact that a large percentage of car drivers park for free or for a price far below the marginal cost (Arnott et al, 1991; Calthrop et al, 2000; Shoup, 1995 and 1997; Small, 1997). The consequence is that parking is largely subsidized or, in the words of Shoup (2005, p.218) "(the) cost of... parking has been shifted into higher prices for everything else".

\subsubsection{Marketing}

Within parking policy marketing is mainly used to promote the efficient use of existing parking infrastructure, or to promote a specific parking facility, i.e. advertisement for specific on and/or off street parking facilities. Sometimes it is coupled with the promotion of sustainable mobility. For example P\&R facilities can be promoted to encourage people to not enter the city centre by car. Underutilized parking garages located outside the busiest downtown areas might be promoted to reduce search traffic. Sometimes marketing parking facilities can bring the attractiveness of

\footnotetext{
${ }^{2}$ Note that in policy instruments literature regulations are often presented as opposed to pricing, but in this case we propose to include pricing in parking regulations policies, because pricing can be seen as a part of overall parking regulations policies, as we will explain later in the paper.

${ }^{3}$ Source: http://www.telegraph.co.uk/news/features/4029123/Time-runs-out-for-the-parking-meter.html, accessed in July 2014.
} 
specific shopping areas under the attention of potential customers. Sometimes the marketing of a shopping centre explicitly includes the attractiveness of parking at that centre.

\subsubsection{Information and communication}

Information and communication systems - e.g. real time information on the available number of parking spaces and/or guidance systems - are used to guide people to available parking spaces and avoid unnecessary cruising or driving through busiest roads or areas. These systems range from traditional traffic signs and boarding to the internet, to in-car navigation systems and smart phone apps. The latter can also be used to pay for parking.

\subsection{Policy aims}

Now that we have discussed the links between instruments and key elements we introduce policy aims to which parking policies can contribute.

In European cities parking policy has always been part of the more general urban transport policy. Accordingly it has followed the major trends that have characterized transport policy in the last decades (van Wee and Annema, 2013). From its first appearance in the 60's till the 80's parking policy has followed the "predict \& provide" principle. This period has witnessed a spectacular increase in welfare and car ownership and, being the negative aspects of car use not considered as an urgent problem, parking policy was mainly used to accommodate the increasing number of urban car users. Parking norms have been constantly revised upwards and the city's total parking capacity kept growing. In the 90's there has been a shift in transport policy towards the "command $\&$ control" principle. Accordingly local authorities reduced the growth of the total parking capacity and started to better regulate and use the existing one, mainly by means of the price mechanism. Finally, since the early 2000s urban transport policy has focused on the "managing demand" principle and parking has become an integrated part of Transportation Demand Management policies (Litman, 2006; Rye and Ison, 2006).

Reviewing the existing literature and the policy documents of the major cities in the UK and the Netherlands we might say that nowadays parking policy has four main objectives:

1. To contribute to a better accessibility and mobility of the urban area ${ }^{4}$;

2. To contribute to a better quality of life in the city (mainly a better air quality and quality of the living environment);

3. To support the local economy.

4. To raise municipal revenue.

\footnotetext{
${ }^{4}$ While in the literature (Levine and Garb, 2002) there is a clear distinction between accessibility and mobility of urban areas, in practice these two terms are often used as synonymous in policy documents.
} 
While objectives one to three are usually explicit, the fourth usually is not. This is because local authorities don't want to associate the idea of paying for a parking space with municipal fund raising. However, since the 2004 Traffic Management Act came into force, English local authorities have been forced by central government to publish an annual report that sets out clearly how much money they raised from the parking operation, and how they spent this money. 


\section{Evolution of parking policy}

Despite their unique character, most European cities follow the same pattern when it comes to parking policy (figure 1). Within this pattern we distinguish three phases each of them consisting of one of more stages. This section describes these phases and relates them to policy aims and instrument discussed in section two. Table 1 provides an overview of the stages and the link between section two and three of the paper.

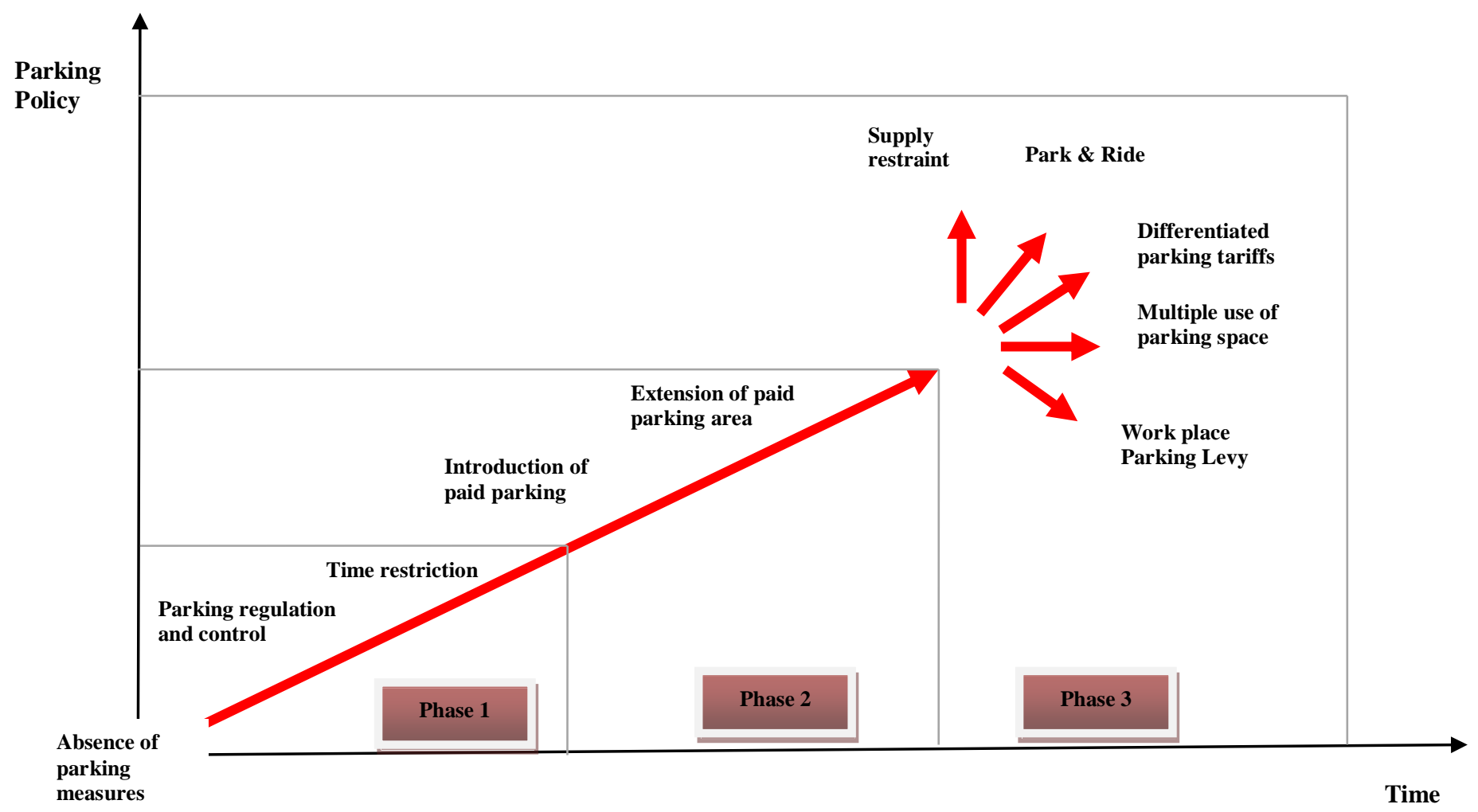

Figure 1: the staged development of urban parking policy.

\subsection{Phase One: The rise of parking regulation}

\section{Absence of explicit parking measures}

At the very beginning any form of parking regulation is absent. In this first stage both car ownership and car traffic are extremely low, and there is abundant space in the urban area to host cars parked mainly on-street with no necessity to charge for it. Accordingly, parking is not considered as a problem at the city level and no formal policy is made for it. Many cities in UK and the Netherlands were in this stage in the first half of the 20th century. Nowadays this might be the case only in remote villages and smaller towns such as High Bentham in North Yorkshire in England, or Inverary in Argyll in Scotland, where parking demand can be managed sufficiently by piecemeal on-street controls to address very site-specific safety problems, and where on-street parking is otherwise unrestricted.

\section{Basic Parking regulation}


As the level of car ownership and traffic increase, cities start to introduce the first form of parking regulations and control mainly in the city centre and/or in the Central Business District (CBD).

The supply of parking starts to be regulated. The main aim of parking policy is to regulate demand in order to facilitate car use. In certain areas parking is prohibited and in other areas parking spaces are clearly marked. Still, most of the parking capacity is on-street and free. In this stage parking standards - usually as minimum - make their first appearance. At present almost all European cities and towns have some basic forms of parking regulation.

\section{Time restrictions}

As pressure on the available parking spaces increases, time restrictions are introduced in the busiest streets or parts of the city (i.e. CBD and main shopping areas). Motorists are allowed to park their cars for a restricted period of time, usually no more than a couple of hours, but still are not asked to pay a price for it. Parking enforcement is introduced in this stage. This kind of policy stimulates short stay parking and is often introduced to maximize the number of visitors (usually shoppers) to the central area.

\subsection{Phase Two: The advent of pricing parking}

\section{Introduction of pricing parking}

Phase two begins with the introduction of paid parking. Rising urban density, welfare and car ownership boost car use in urban areas increasing the parking problem. The demand for parking space clearly exceeds the supply causing congestion - both to enter the city centre and to search for a parking space - and illegal parking. In order to reduce these problems and to regulate demand, parking fees are introduced initially in the city centre. Usually, the areas where first time restriction was introduced are now the first to be regulated through pricing parking.

The very first parking meters were introduced in 1935 in Oklahoma City, in the USA (Shoup, 2005). In the Netherlands it was Schiphol (Amsterdam) airport the first place were parking meters appeared. Amsterdam was the first Dutch city to introduce paid parking, placing 500 parking meters in 1964 (CROW 2012). In 2014 a total of 155 municipalities in the Netherlands had some forms of paid parking, compare to 126 in 1989; paid parking is nowadays active in all cities with more than 100,000 inhabitants and in one third of the cities with a population ranging between 20,000 and 50,000 inhabitants 5 . In England the first parking meter was installed on London's Grosvenor Square in July $1958^{6}$. However, local authorities have been able to take over the enforcement of on-street parking from the police since the Road Traffic Act was passed in 1991

\footnotetext{
${ }^{5}$ Source: http://www.cbs.nl/nl-NL/menu/themas/overheid-politiek/publicaties/artikelen/archief/2014/2014-4043wm.htm, accessed in June 2014..

${ }^{6}$ Source: http://www.telegraph.co.uk/news/features/4029123/Time-runs-out-for-the-parking-meter.html, accessed in July 2014
} 
(the same legislation also required London authorities to make this change). Any authority so doing must introduce some form of charging since the operation is required to be self-financing. In 2000 only 28 English local authorities outside London used these decriminalised powers in at least part of their area, and DfT (2006) reports a "a significant expansion of Decriminalised Parking Enforcement" between 2001 and 2006, which continued into the second half of the same decade, such that by 2010, 265 authorities have used the powers to charge for and enforce parking restrictions in their area ${ }^{7}$.

The introduction of paid parking is sometimes accompanied by the introduction of residents' and/or working parking permits. People living and/or working in the areas where pricing parking is active might be entitled to receive a permit to park their car. Initially the parking permits might be free, especially for residents; in a later stage a fee is usually asked for. The enforcement activities increases accordingly; traditionally being a low-skill, labour-intensive activity, parking enforcement often is used to create "social" jobs. Parking standards, in some countries suggested or required by national authorities, are in this stage regularly applied to new development project in the urban areas.

The first purpose-built public off-street parking facilities start to emerge in this stage. The possibility to ask for a parking fee stimulates local authorities and private companies to invest in parking garages.

\section{Extension of the paid parking zone}

As time goes on, the area where pricing parking is active is usually extended. Many drivers tend to park in surrounding (often residential) areas to avoid the payment of a parking fee in the city centre. This increases the parking pressure on these areas (i.e. demand exceeds supply) causing protest especially among residents who might experience difficulties in finding a parking space for their own. As a reaction to the complaints of the residents the local authority usually decides to extend the area of paid parking. This reactive mechanism repeats itself every time the paid parking area attracts more visitors. This phenomenon is known as the "snowball effect" of paid parking or "spill over effects" or, in the words of Ison and Rye (2006, p. 445) as "the boundary effect resulting from the implementation of an area parking policy". Ultimately in the whole inner-city a paid parking regulation system might be present. For example, at the moment of writing this paper (July 2014), in the whole inner-city of Amsterdam is pricing parking active (see figure 2). From a situation in the early 1990s where unrestricted on-street parking was available in the inner London Borough of Camden within a 20 minute walk of London's central business district, the local authority has gradually introduced more parking restrictions until today, when on-street parking in

\footnotetext{
${ }^{7}$ Source: http://www.telegraph.co.uk/motoring/news/6968607/Motorists-hit-with-ghost-tickets.html, accessed in June 2014.
} 
its entire area is now controlled (London Borough of Camden 2007). As rule of thumb local authorities introduce (or adjust) price parking when the occupancy rate is above $80 / 85 \%$.

This stage is also characterized in the Netherlands by the increased use of off-street, often underground, parking facilities. Both local governments and private developers provide additional supply in order to meet the rising demand in the most attractive parts of the city. Increase lack of space, higher land values and a trend towards a better quality of the living environment have caused a shift at first from on-street to off-street parking and, later, from above-ground to underground parking. The UK has witnessed less of this trend - new public off-street parking has been built only in very city centres associated in the main with new retailing, and railway stations. New purpose built off-street parking to accommodate demand from residents whose own homes were originally built without parking is almost unheard of.

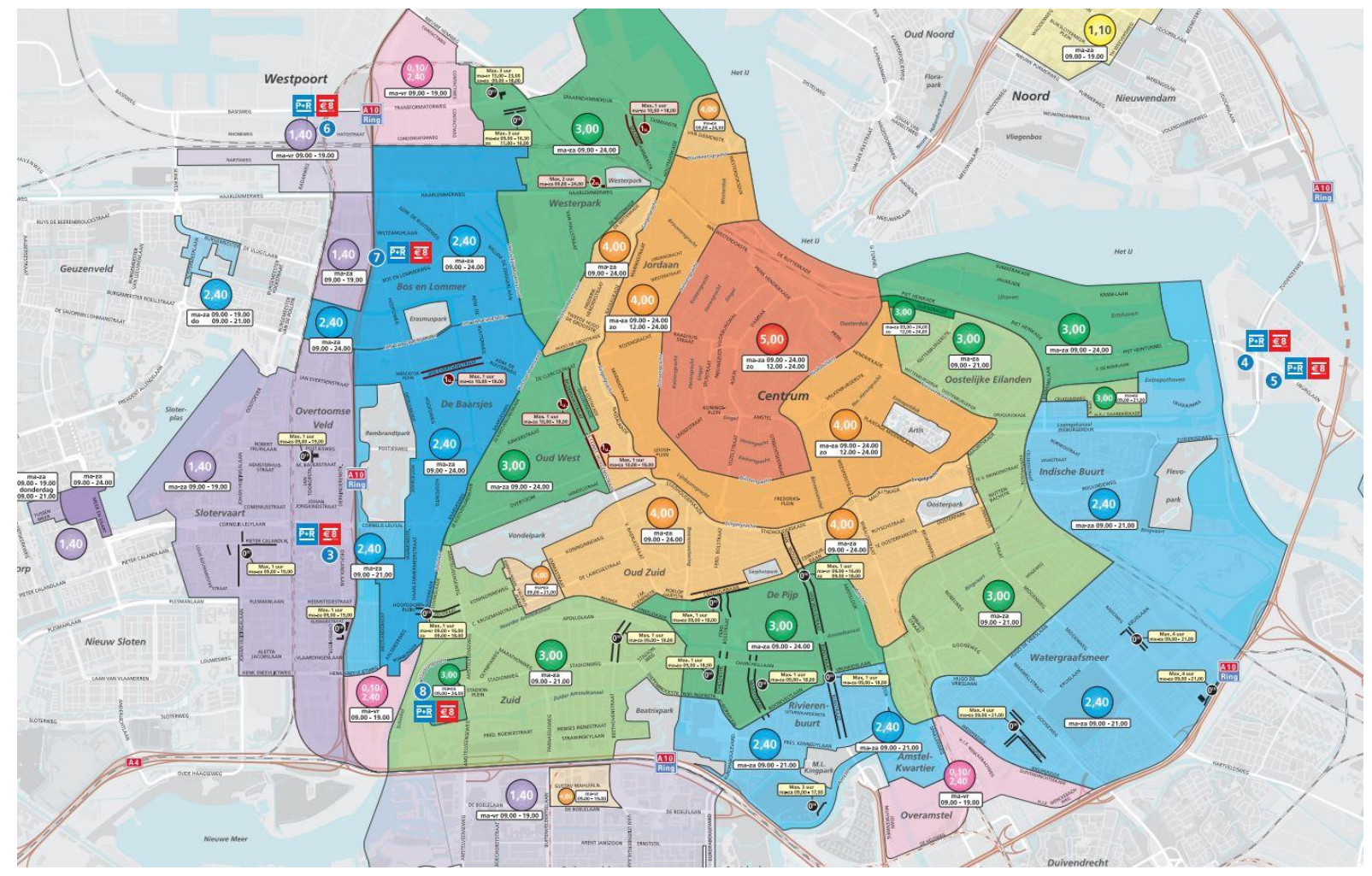

Figure 2: pricing parking in the city of Amsterdam in 2014: the different colours indicate different hourly fees (Source: http://www.parkerenindestad.nl/amsterdam, accessed in July 2014 .

\subsection{Phase Three: Parking policy as integral part of TDM strategies}

Phases one and two are characterized by a reactive parking policy. Policy makers simply introduce specific parking measures in reaction to the rise of a specific problem. The different stages of development in these two phases simply follow each other. Most cities in Europe have followed a similar evolutionary pattern (EU, 2005; Kodransky and Hermann, 2011).

Quite different is the situation in phase three. The increase attention towards quality of life and environmental standards coupled with the increasing costs of providing extra parking capacity - 
due to scarcity of land and high costs of building (underground) off-street parking - push policy makers towards a better management of parking demand. Parking becomes an integrated part of transport demand management practices (Litman, 2006; Ison and Rye, 2008) and gets a higher rank on the urban political agenda and in the planning process. Large cities consider parking as a major tool to improve accessibility, to stimulate local economy and to achieve a higher quality of life. In this phase a broader vision on parking emerges where parking is more integrated with the general aims of the city in terms of mobility, urban planning and environmental quality. In this phase the shift in policy from "command \& control" to "managing demand" (see section 2.2) takes place. This is similar to the shift suggested by Litman (2006) from the old to the new Parking Paradigm. The key elements of parking supply and the policy instruments should then change accordingly. We can see typical policy objectives in the example below, showing the stated objectives for parking policy from Edinburgh (UK):

"The overall objective for the parking strategy is to manage parking to support wider Council economic, environmental and social policies, recognizing the competing demands for space. More detailed objectives are to:

$i$ Use parking policy to help to maintain and improve the economic vitality of the city centre and traditional district and local shopping centers, relative to other centers;

ii Ensure that parking provision does not encourage commuter car travel, especially to the city centre, and relates to the ease of access by public transport, cycling and walking;

iii Minimize the negative impacts of parking on the streetscape, especially in environmentally sensitive areas, and on public and private space in new developments;

iv Improve road safety and reduce congestion and pollution;

$\checkmark$ Facilitate access and movement by mobility impaired people, pedestrians, cyclists, public transport and its users, and motorcyclists;

vi Protect and, where possible, enhance residents' ability to park and load close to their homes;

vii Protect and, where possible enhance the parking and loading needs of businesses, tradespeople, carers and visitors;

viii Facilitate the operation and expansion of Car Clubs"

Taken from City of Edinburgh Council Local Transport Strategy 2007-2012.

Most cities use the suggested regular parking requirements as guidelines to set their own minimum and maximum requirements (see section 2.1.1). Besides a further extension of the priced areas onstreet, some new measures are introduced, the most important being: supply restraint; Park and Ride (P\&R) facilities; differentiated parking pricing; the introduction of multiple use of parking space; and workplace parking levies.

\section{Supply restraint}

Probably one of the most strategic policy measures that characterize the third phase is the introduction of reductions or restrictions to parking supply in the city centre and in transit oriented developments (TOD's). Many large cities in Europe have introduced some form of supply reduction since decades. London started in the seventies with the implementation of the 1976 Greater London Development Plan (Lester, 2013; White, 2008). Copenhagen started reducing 
parking spaces in the city centre in the sixties; between 1995 and 2000 the Danish capital removed approximately 400 parking spaces, approximately $1 \%$ of the total on-street paid parking supply (Kodransky and Hermann, 2011). In the last decade Paris has reduced overall on-street parking supply by $9 \%$, or 14,300 spaces (Kodransky and Hermann, 2011). Restrictions are usually related to lower parking standards for new developments depending on the public transport accessibility. In the literature this is often associated to the concept of TOD's (Litman, 2006). In Europe there are several examples of this kind of supply restraints; among others in Antwerp (GAPA, 2008) and in Munich (Kodransky and Hermann, 2011). Probably the most famous example of this was the so-called "A-B-C planning policy" introduced in the nineties in the Netherlands, where parking standards for new developments were set by the Ministry of Transport and related to the distance of the new development to the nearest public transport station (Van den Bergh and Verhoef, 2001). Interestingly, this policy - probably the first attempt in Europe to create a national parking policy - has been abolished because local authorities wanted to have more freedom to set their own parking standards. Zurich applies a similar system - i.e. parking standards based on transit accessibility - and since the nineties has introduced a supply cap system (Fellmann et al, 2009). If a parking space is created off-street in the historical inner-city, an on-street parking space must be removed in order to keep the supply equalized (Kodransky and Hermann, 2011; p. 69).

\section{Park and Ride}

Three types of Park and Ride (P\&R) facilities can be distinguished (Mingardo, 2013): remote P\&R (close to user's home), peripheral P\&R (usually located at the edge of urban areas) and local $\mathrm{P} \& \mathrm{R}$ (along main transport corridors). $\mathrm{P} \& \mathrm{R}$ has been probably one of the aspects of parking that has received the largest attention in the scientific literature: among others Merriman (1998), Parkhurst (2000; 2002), Meek et al (2009; 2010 and 2011) and Mingardo (2013). Most of them suggest that this kind of parking facility might also have some negative effects.

In the Netherlands the first official P\&R was introduced in 1979 in Schagen, a small town located north of Amsterdam, as joint initiative of the national railway (NS) and the national car drivers association (ANWB) with the financial support of the Ministry of Transport. Since then, this kind of parking facility developed very quickly. By the end of the eighties more than fifty official P\&R were in used; 386 P\&R facilities were counted in the country in 2003 (Crow, 2004). Nowadays there are more than 400 P\&R functioning in the Netherlands. UK DfT (2006a) found that between 2001 and 2006 English local authorities used government transport funding to build 54 new bus based P\&R schemes and to extend 33 existing schemes; and to build 22 new rail based schemes, and extend a further 59. Thus in England also, $P \& R$ has become an important plank of local transport policy.

For example Rotterdam has approximately 9,000 spaces in the $32 \mathrm{P} \& \mathrm{R}$ facilities located around the city, while in the city centre the total (regulated) parking supply on- and off-street is 
approximately 65,000 places (Stadsregio Rotterdam, 2013). This leads to a ratio of 0.14 P\&R space for each parking place in the city centre. A similar ratio (0.13) can be found in Amsterdam: the city has 3,600 P\&R spaces and a total of 27,059 regulated parking spaces in the centre (Grooten, 2014)

\section{Differentiated Parking tariffs}

Differentiated parking fees - according to location, time and/or type of vehicle - might be introduced in order to make an efficient use of (scarce) parking capacity. In several cities this is considered as an efficient tool to regulate traffic and/or to apply the "polluter pays" principle in the attempt to reduce pollution caused by motor vehicles. Normally speaking parking fees are highest in the city centre and/or in the CBD and decrease gradually with distance from these central locations. Three major innovations took place in the last decennium in the methodology used to calculate parking tariffs: (1) variable fees according to demand for parking; (2) variable fees according to vehicle's emissions and; (3) real-time parking fees.

(1) In the first years after the introduction of paid parking, parking fees were mainly differentiated on the base of the time of day (e.g. at night parking fees are lower than during the day or even absent) and on the day of the week (e.g. during weekends fees might be lower than during the week). In the last decade the pricing scheme has changed in many cities and towns where onstreet parking fees might vary several times during the day according to the expected parking demand. While having different prices in different areas of the city is a longstanding practice, the effort to make these variations respond more quickly and precisely to variations in demand can be seen as an innovation. For example Rotterdam was one of the first cities to introduce parking tariffs based on demand in the early 2000's. A minimum fee of $€ 0.50$ was applied per time window; this varies from 10 minutes ( $€ 3$ per hour) to 20 minutes ( $€ 1.5$ per hour) according to the expected parking demand on the street (Gemeente Rotterdam, 2010). When the occupancy rate was above $80 \%$ the parking fee was increased; when it was below $60 \%$ the fee was reduced. Interestingly the city has decided to stop with this system as for January 2012 (Bos et al, 2013). At present the price differentiation is still in place but the effort to adjust the prices on demand has been abandoned. More recently the city of San Francisco has introduced what is probably the first large scale scheme that applies fees that vary according to actual demand. For a comprehensive description and evaluation of this scheme see Pierce and Shoup (2013). Madrid is following the San Francisco example; from July 2014 the onstreet tariff will be related not only to the type of vehicle (see point 2 in this section) but also to the actual demand. Motorist pay $20 \%$ and $10 \%$ less when the occupancy ratio is, respectively, below $30 \%$ and between $30 \%$ and $60 \%$; they pay the normal price when the 
occupancy ration is between $60 \%$ and $85 \%$; they pay an additional $10 \%$ or $20 \%$ when the ratio is, respectively, between $85 \%$ and $95 \%$ or above $95 \%$.

(2) Recently in the Netherland there has been a proposal to modify the national law in order to allow cities to apply different parking fees according to energy label of the vehicles. A recent study (CROW, 2010) suggests that this kind of parking policy might have a positive effect in terms of $\mathrm{CO}_{2}$ emissions but it might be difficult to implement. However in 2011 the parliament decided not to approve such a proposal (Stumpel-Vos and van de Vosse, 2012). A real example can be found in the UK. In London, the borough of Richmond has probably been the first local authority in Europe to introduce parking fees based on the emissions of vehicles: the more pollutant the vehicle is, the higher the fee that has to be paid to park in the borough. This held both for residents and business permits. In 2008 relatively very environmental friendly cars $\left(\mathrm{CO}_{2}\right.$ emission equal or lower than $\left.100 \mathrm{~g} / \mathrm{km}\right)$ could get an annual parking permit for free, while the most polluting cars $\left(\mathrm{CO}_{2}\right.$ emission equal or larger than $\left.225 \mathrm{~g} / \mathrm{km}\right)$ had to pay a higher fee: $£ 300$ for resident permits and $£ 1,800$ for business permits (Mingardo et al, 2008). The policy became very politically controversial locally and was overturned when the ruling Liberal Democrats lost a local election to the Conservatives. However, councils such as Edinburgh and several other London Boroughs have since introduced similar tariffs related to vehicles' environmental performance. Madrid is the first city in Europe to introduce a similar scheme on a wide area; as for July, $1^{\text {st }} 2014$ the fee motorists have to pay for on-street parking depends on the engine type and construction year. Electric vehicles can park for free; hybrids have a $20 \%$ reduction while heavy polluting vehicles pay $20 \%$ extra $^{9}$.

(3) Finally, one of the most important trends in parking tariffs regards the introduction of the so called "real time parking fees", which refers to the application of a parking fee per minute. Normally speaking fees are calculated per hours or by other fixed time periods (e.g. per 30 minutes). Recently this has created some doubts on why the consumer should pay for a larger period of time than what he actually uses. The technological development - namely ticketing machines, sensor technology and payment through mobile phones or in car navigation systems - makes possible to charge drivers for the exact amount of time they park their cars. Spain is the only country in Europe where a national law obliges all off-street private operators to charge drivers per minute since $2006^{10}$. In the Netherlands, at the moment of writing, only a few off-street parking facilities apply parking fees per minute. However, the use of mobile phones to pay has increased dramatically in the last years: in 2010 approximately one third of all parking transaction in Amsterdam was done through the use of mobile phones ${ }^{11}$; at present

\footnotetext{
${ }^{8}$ Source: http://ccaa.elpais.com/ccaa/2014/04/29/madrid/1398763987_835610.html, accessed in July 2014.

${ }^{9}$ Source: http://ccaa.elpais.com/ccaa/2014/04/29/madrid/1398763987_835610.html, accessed in July 2014.

${ }^{10}$ Source: http://www.20minutos.es/noticia/242274/0/minutos/parking/ley/, accessed in July 2014.

${ }^{11}$ Source: http://www.at5.nl/artikelen/41836/belparkeren-steeds-populairder, accessed in July 2014.
} 
(2014) this share is expected to be above 50\%. Despite the fact that real-time parking is mainly an operational issue led by new technologies, it does have a strategic component. First, it brings a new important player in the parking sector, namely the service providers - i.e. the company providing the app to pay by phone. At the moment this service providers are different from the parking operators. Second, a large scale implementation of real-time parking fees might lead to a (large) revenue reduction both for public and private operators.

\section{Multiple use of parking facilities}

Increasing construction costs of parking facilities and the trend to store cars underground - to gain additional space above ground for other urban functions - are the main factors explaining the introduction of multiple use of parking facilities. This concept is known in North America as 'shared parking'; parking spaces are shared by more than one user, allowing for more efficient use of parking facilities ${ }^{12}$. The main idea is to use parking garages and parking lots more intensively. So, for example, the parking lot of a theatre is used during the day by the employees of companies located nearby and in the evenings by the theatre visitors. A downtown garage can be used during the day for the visitors of the city and during the night for the local residents.

Not only off-street parking can be used for different users, but it can also be used and/or combined for different purposes. For example, the noise barriers along the A12 motorway near the Dutch city of Ede are also used as parking garage (see figure 3). Another example is the underground parking garage Museumpark in the centre of Rotterdam that can be used, when necessary, as water storage.

Also on-street parking can be used for different users. Copenhagen introduced in 2011 a pilot project with flexible on-street parking: five parking spaces in front of a secondary school are dedicated for bike parking between 7:00am and 5:00pm and for car parking for the remaining period $^{13}$ (see figure 4 ).

The trend towards an increasing use of shared parking can be seen as part of a more general trend, namely a shift away from requiring so much private off-street parking towards an emphasis in making better use of existing (public and private) supply. This trend has already been reported by Shoup (2005) when he introduces the concept of providing public parking in lieu of private parking as a way to eliminate (or reduce) off-street parking requirements. The author provides an overview also of number of European examples, namely in United Kingdom and Germany (Shoup, 2005; p. 230).

\footnotetext{
${ }^{12}$ Source: http://www.vtpi.org/tdm/tdm89.htm, accessed in October 2012.

${ }^{13}$ Source: http://www.cycling-embassy.dk/2011/08/22/experiments-with-flexible-parking-in-copenhagen/ ,accessed in December 2013.
} 


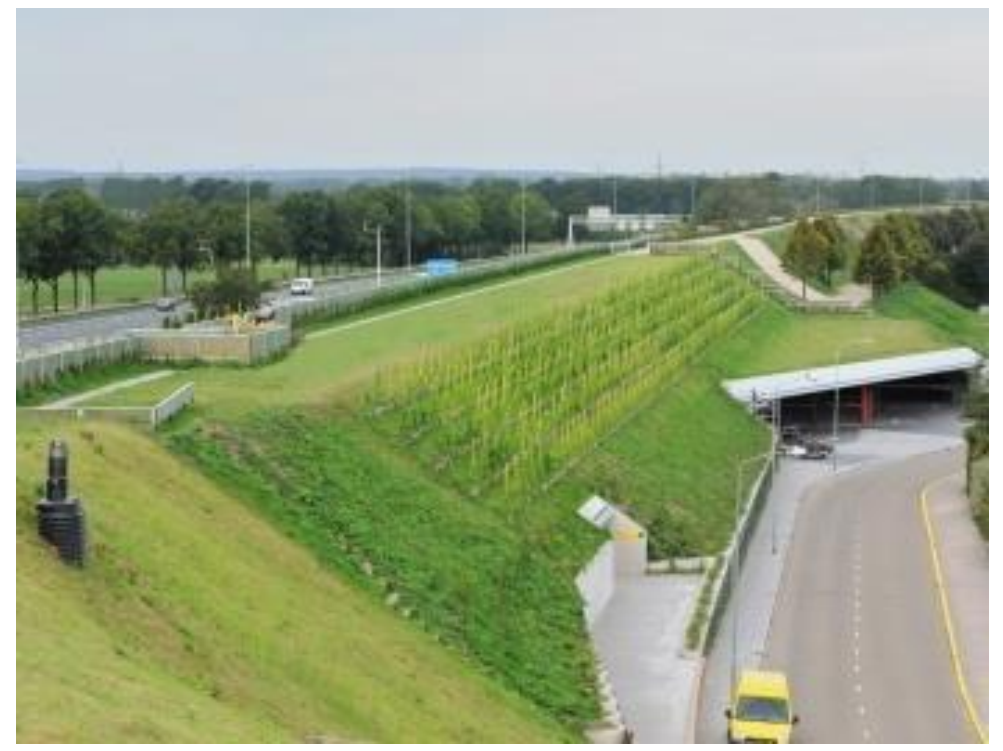

Figure 3: the parking garage of the CineMec in Ede is built into the noise barrier for the A12 motorway in the Netherlands.

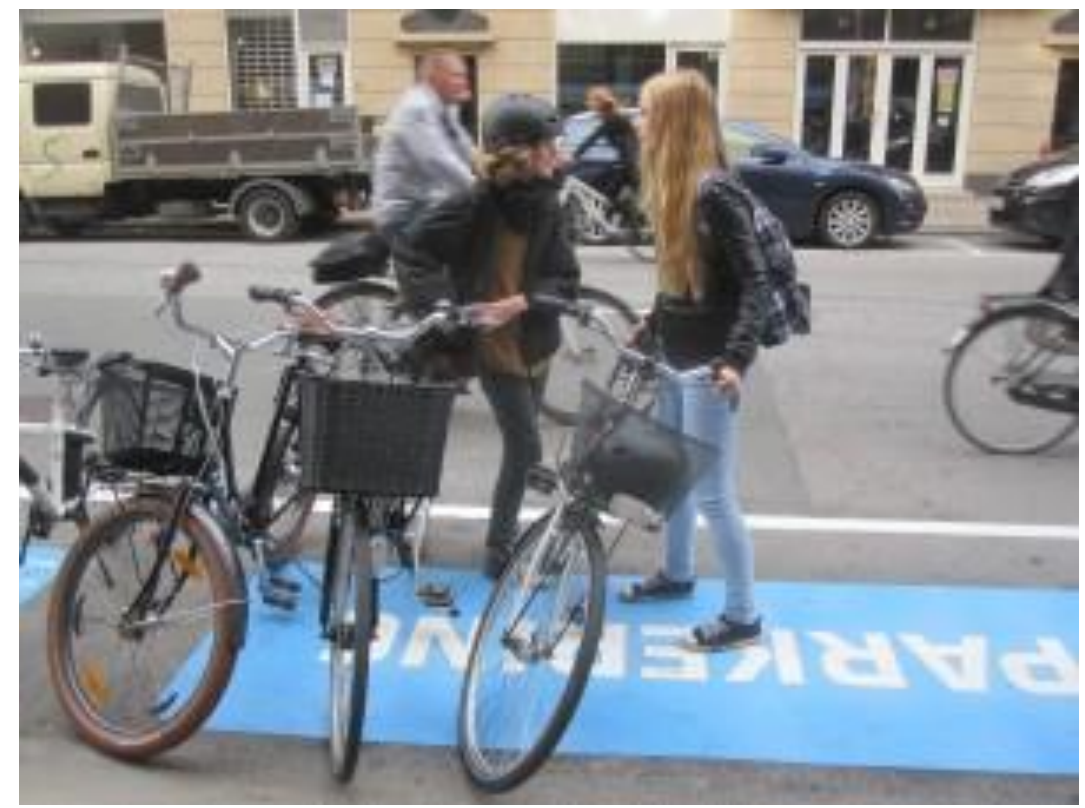

Figure 4: flexible on-street parking in Copenhagen (source: http://www.cycling-

embassy.dk/2011/08/22/experiments-with-flexible-parking-in-copenhagen/, accessed in December 2013).

\section{Workplace Parking Levy}

A workplace parking levy (WPL) is a tax on private non-residential parking provided by

employers, off-street, for their staff. Local authorities in England and Wales are permitted, under the UK Transport Act (2000), to introduce such a tax, subject to final approval of the scheme by national government. However, to date, only one local authority, the City of Nottingham, has introduced such a scheme, and then only in April 2012 - currently (July 2014) employers with more than 10 staff are required to pay the City Council (municipality) 288GBP (around 350 Euros) per year for each space in use. In England and Wales the lack of other cities that have 
implemented the measure may be explained by political fears about its possible impacts on economic development; and in other countries in Europe, such a levy is not currently legally permitted. 


\section{The need for a strategic approach}

The major shift in urban parking policy occurs when a city enters phase three. In phase one and two parking policy has always tended to be rather reactive and rather operationally focused, failing to see parking in a holistic urban (transport) planning context. Urban planners and policy makers, during these phases, simply follow the consecutive steps - i.e. time restriction, pricing parking, and extension of the pricing area - in a rather reactive way. When a specific parking problem occurs, for example spillover effects at the edge of the paid parking area, the corresponding solution is implemented - extension of the pricing area. This approach might work for phases one and two but by the time a city moves to phase three the pressures of parking are such that a more strategic approach is required.

\begin{tabular}{c|c|c}
\hline $\begin{array}{c}\text { Reactive/Operational approach to } \\
\text { parking policy (phase 1 and 2) }\end{array}$ & $\begin{array}{c}\text { Strategic/Evidence Based approach to } \\
\text { parking policy (phase 3) }\end{array}$ & Main advantages of phase 3 \\
\hline $\begin{array}{c}\text { Parking policy is not seen as an important } \\
\text { part of urban policy. }\end{array}$ & $\begin{array}{c}\text { Parking policy has a holistic approach and is } \\
\text { fully integrated in the urban (transport) } \\
\text { planning context. }\end{array}$ & $\begin{array}{c}\text { Parking does not work against other policy } \\
\text { objectives, i.e. increasing transit or } \\
\text { livability in urban areas. }\end{array}$ \\
\hline $\begin{array}{c}\text { Parking policy is mainly reactive, } \\
\text { implementing measures only when a } \\
\text { problem arises. }\end{array}$ & $\begin{array}{c}\text { Parking policy is mainly proactive - i.e. it } \\
\text { tries to prevent (parking) problems from } \\
\text { occurring. }\end{array}$ & $\begin{array}{c}\text { It facilitates TDM strategies and increases } \\
\text { the acceptance of parking policy. }\end{array}$ \\
\hline $\begin{array}{c}\text { Basic data about parking supply are not } \\
\text { available and/or used. }\end{array}$ & $\begin{array}{c}\text { Parking supply is properly inventoried. Data } \\
\text { are used to support decision making. }\end{array}$ & $\begin{array}{c}\text { Better investment decisions lead to more } \\
\text { efficient use of (scarce) resources. }\end{array}$ \\
\hline $\begin{array}{c}\text { Parking requirements are based on national } \\
\text { guidelines often applied with little or no } \\
\text { flexibility. }\end{array}$ & $\begin{array}{c}\text { Parking requirements are flexible and set in } \\
\text { accordance to meet the needs of both public } \\
\text { authorities and private developers. }\end{array}$ & $\begin{array}{c}\text { Better investment decisions lead to more } \\
\text { efficient use of (scarce) resources. }\end{array}$ \\
\hline $\begin{array}{c}\text { Marketing and communication are reduced } \\
\text { to the minimum - i.e. information on how } \\
\text { the system works. }\end{array}$ & $\begin{array}{c}\text { Active communication is used to explain the } \\
\text { role of parking in urban areas. }\end{array}$ & $\begin{array}{c}\text { Improved understanding of parking policy, } \\
\text { better image for parking management. }\end{array}$ \\
\hline $\begin{array}{c}\text { Decision making very intuitive leading to } \\
\text { wrong (expensive) investment decisions. }\end{array}$ & $\begin{array}{c}\text { Decision making is based on data analysis. } \\
\text { Better investment decisions lead to more } \\
\text { efficient use of (scarce) resources. }\end{array}$ \\
\hline
\end{tabular}

Table 2: Comparison of the main approach of phases 1 and 2 with phase 3

The strategic approach we advocate firstly requires the full integration of parking policy within general urban and transport policy and, secondly, making parking policy part of a broader demand management strategy. In order to achieve this, some of the major shifts that must occur in policy making are the following (see Table 2):

- The supply of parking - i.e. the key elements (see section 2.1) - must be adequately inventoried. Currently, most cities lack basic data such as total parking capacity, a clear distinction between private and public parking capacity, and information about the use of parking. For example, in spite of the fact that all transactions made through modern on-street 
Pay and Display ticketing machines are registered, these data - containing among other information about the number and the length of parking transactions - are rarely used by policy makers. Indeed many policy makers are simply not aware of the fact that these data are available at all. It is very difficult to manage demand (for parking) properly if little is known about (parking) supply. The city of Leiden in the Netherlands (Gemeente Leiden, 2014) and the city of Treviso in Italy (Crosato, 2011) are good examples of cities that collect data about parking transactions and use them to support decision making.

- There is a need to re-think parking requirements in the light of the inadequacy of national guidelines. Both Shoup (1999, 2005 and 2013) and Litman (2006) have criticized the way in which parking requirements are influenced by national guidelines. Not only do they have to be flexible, considering the specific characteristics of each site and activity; parking norms also have to find the right trade-off between the needs of the public authority - principally to prevent spillover effects and undesired car traffic - and the needs of private developers which are mainly to reduce costs and/or to build attractive properties. Ultimately, the new strategic approach to parking would lead to parking standards defined per area and not, as it is currently the case, per building; be expressed as a range, to take account of local context; and linked to accessibility by other modes. Policy makers and planners should consider the total parking supply in the area before requiring new capacity, and seek ways to allow multiple uses of parking facilities (see section 3.3). For example in the city of Utrecht parking requirements are lower when applied in areas with on-street paid parking (Gemeente Utrecht, 2013). Zurich, besides its supply cap system (see section 3.3), applies parking standards for new developments based on the level of public transport accessibility (Kodransky and Hermann, 2011).

- National government should play an active role in encouraging cities to take a more innovative approach to parking policy, both management of existing parking, and construction of new supply; and in highlighting to them the need to place parking policy within a wider strategic transport planning context, such as that of a sustainable urban mobility plan (SUMP; European Commission, 2011). It is interesting to note the role of such guidance from English central government in encouraging cities in England to take action on parking over the first decade of the $21^{\text {st }}$ century (see UK DfT, 2006b and 2007; UK Department for Communities and Local Government, 2012).

- Marketing and communication must play a fundamental role within parking policy. Parking has often a bad image among drivers and retailers (both thinking it should be abundant and for free) and even among politicians (seeing it as a difficult portfolio for which to take responsibility). Often the only communication about parking provided by the local authority is about how the system works - i.e. time restrictions, ticketing machines, permits, etc. Hardly any city communicates why the system is in place - that is, why the user should pay for 
parking, how parking income is utilized, and so on. The San Francisco parking scheme mentioned earlier is a good example of this: in the words of the authors "... SF park helps to depoliticize parking by stating a clear principle for setting the prices for curb spaces" (Pierce and Shoup, 2013: p. 69). Another interesting example is provided by the town of Roermond (the Netherlands) that has recently communicated that the extra income generated by the increase in parking fees goes to a so called "mobility fund" which is used to improve the overall accessibility of the city ${ }^{14}$. English municipalities are now required (since 2008) to publish an annual report describing their parking operation, how much money they raised from parking charges and from fines, and what they have done with the money raised; however, how well the municipalities publicise this report is their own decision.

- Finally decision making should be based on knowledge and facts. Information must be carefully collected and analysed before taking (expensive) investment decisions. Data collection and analysis are used in many sectors within transport like railway companies, airlines and car manufactures. Parking has simply become too important and too expensive for public authorities and decision making to be based on anything other than sound knowledge. Nowadays, most of cities and towns in Europe have entered (or are entering) the third phase, but there remains a tension between the reactive/operational approach to managing parking, and the more strategic, evidence based approach that we advocate here. This is not least because parking remains managed by parking managers, whose focus is by necessity operational, whilst wider transport strategy and the role of parking within it is more normally dealt with by strategic transport planners, whose focus is less reactive and operational. Communication between the two may not always be regular, or optimal.

\footnotetext{
${ }^{14}$ Source: http://roermond.gezien.nl/nieuws/mobiliteitsfonds-roermond-opgericht.html accessed inJune 2014.
} 


\section{Concluding remarks}

Although research on parking has substantially increased in the last decade, an overall conceptualisation of the evolution of parking policy is still missing. The most relevant earlier work is probably that of Shoup (2005), Litman (2006) and Barter (2010). In different ways they all suggest a shift away from the conventional "predict \& provide" approach to parking policy. Their work is mainly based on the North-American planning experience. This paper has built on their work, focusing on Europe, and tried to go beyond it by conceptualizing parking policy first, and suggesting the ingredients for a new approach to parking thereafter. Parking policy has always tended to be rather reactive and rather operationally focused, not seeing parking in a holistic transport/urban planning context. This approach might be adequate for phase one and two of parking policy but by the time a city moves on to phase three the pressures of parking are such and not just in city centre areas - that a more strategic approach is required. At this stage, parking policy must become an integral part of general urban and transport policy and a core element of a broader demand management strategy. In order to achieve this, a major shift in the use of parking instruments (section 2.1) must occur. The advantages of a strategic approach, compared to a reactive one, include mainly a better and more efficient use of resources - i.e. reduced costs for the provision and management of parking - and the creation of broader acceptance for parking policy.

Considering the future of urban parking we can identify three major challenges that policy makers will face in phase three, namely:

a) Increasing pressure on the financial aspects of parking policy. The trend towards a larger use of expensive (often underground) off-street facilities, the growing political pressure on parking charges (mainly retailers asking for lower charges) and the increased costs associated with the enlargement and enforcement of the paid parking area on-street can easily lead to a situation where the costs of implementing parking policy rise faster than revenues. For example between 2008 and 2012 many cities and towns in the Netherlands and in England have witnessed a decreased in the income generated by parking fees while the costs of implementing the policy have remain mostly unchanged (Spark, 2013; Moerkamp, 2013; review of Annual Parking Reports in England).

b) The need to decouple new developments from existing parking requirements. As mentioned in section four, rigid parking standards are not appropriate for managing parking in phase three. National guidelines (on parking standards) are simply not able to reflect adequately the site-specific characteristics of new development. For example a growing number of private companies are using TDM policies and Travel Plans to reduce 
car dependency among employees and local authorities must consider this when deciding how much parking the company has to provide.

c) The introduction of parking regulations in residential and suburban locations. While the use of active parking regulation - especially pricing - is (more or less) accepted in the central areas of at least medium and larger cities, more controversial will be its acceptance in peripheral residential areas, not to mention in suburban municipalities. A constant increase in welfare and other socio-economic changes - for example more women in work, flexible working hours, changing housing composition and increasing number of immigrants - are leading to higher levels of car ownership in all but central cities. When this happens in residential areas built some decades ago - when car ownership was lower - it leads to significant capacity problems, but the patterns of parking in these areas make standard on-street parking management much less financially viable than in inner areas.

Finally we draw some suggestions for further research. Entering phase three means that policy making becomes even more complex. Urban planners and decision makers, as well as private developers, need to take important decisions on how to invest scarce financial resources. Academic research should try to help them with relevant knowledge to support the decision making process. Academics and parking professionals (policy makers, advisors...) have operated for a long time - in phase one and two - in separate fields. The outcome of this is twofold: on the one hand there is little interaction among the two groups; on the other hand there might be a mismatch between the knowledge produced by academics and the knowledge needed by planners and decision makers. To overcome this gap between the two groups we recommend future research to be carried out, at least in part, in close cooperation with practitioners and focus on policy-related issues. Much under-utilized data on parking are stored in hard disks somewhere by local authorities, waiting to be analysed. And practitioners have many questions that they would like answered, but often lack the skills or knowledge to do so. Future research should aim to bridge this gap in order to produce more evidence based, and ultimately, more cost-effective parking policy. 


\section{Literature}

Arnott, R., De Palma A. and Lindsey, R. (1991) 'A temporal and spatial equilibrium analysis of commuter parking', Journal of Public Economics, Vol. 45, pp. 301-335.

Arnott, R. (2006) 'Spatial competition between parking garages and downtown parking policy', Transport Policy, Vol. 13, No. 6, pp. 458-469.

Arnott, R. and Inci, E. (2010), ‘The stability of downtown parking and traffic congestion', Journal of Urban Economics, Vol. 68, No. 3, pp. 260-276.

Barter, P. (2010) 'Off-street parking policy without parking requirements: a need for market fostering and regulation', Transport Reviews, Vol. 30, No. 5, pp. 571-588.

Bos, E., Hulsbeek, S. van de and Stienstra, S. (2013) 'Geslaagd Nationaal Parkeercongres 2013', Vexpansie, December 2013, pp. 13-15.

Button, K.J. (2006), 'The political economy of parking charges in "first" and "second-best" worlds', Transport Policy, Vol. 13, No. 6, pp. 470-478.

Calthrop, E., Proost, S. and van Dender, K. (2000), 'Parking Policies and Road Pricing', Urban Studies, Vol. 37, No. 1, pp. 63-76.

Crosato, S. (2011), 'iPark Treviso sosta', presentation given at the PIMMS TRANSFER Masterclass on March, $2^{\text {nd }} 2011$, Treviso, Italy.

CROW (2004), Overstappunten - Ervaringen met Park \& Ride (P+R) in Nederland, available online http://www.crow.nl/shop/webshop.aspx?theme=25\&category=ca3\&subcategory=-1.

CROW (2010), Parkeren en luchtkwaliteit, Publicatie 218m, October 2010

CROW (2012), Handboek Parkeren, CROW, Ede.

DCLG (Department of Communities and Local Government) (2001a), Planning Policy Guidelines 13 Transport, DCLG, London.

DCLG (Department of Communities and Local Government) (2001b), Planning Policy Guidelines 3 Housing, DCLG, London.

Dijk, M. (2010), Innovation in Car Mobility - co-evolution of demand and supply under sustainability pressures, Doctoral Thesis, Maastricht University Press, 2010.

Enoch, M. and Ison, S. (2005), 'Levying charges on private parking: lessons from existing practice'. World transport policy \& practice, Vol. 12, No. 1, pp. 5-14.

European Commission (2011), 'White Paper - Roadmap to a Single European Transport Area - Towards a competitive and resource efficient transport system', Brussels, 28.3.2011, COM(2011) 144 final

European Union (2005), 'Parking policies and the effects on economy and mobility', Technical Committee on Transport; Report on COST Action 342, August 2005.

Fellmann, A., Ott, R. And Willi, E. (2009), 'Der Historische Kompromiss von 1996 - Erläuterungen zu Entstehung und Umsetzung, Mobility Planning Department, City of Zurich, October 2009. 
GAPA (Gemeentelijk Autonoom Parkeerbedrijf Antwerpen) (2008), Parkeerbeleidsplan 2008-2012, Antwerp,

Glaser, B. (1992), Basics of grounded theory analysis. Mill Valley, CA: Sociology Press.

Glazer, A. And Niskanen E. (1992), 'Parking fees and congestion', Regional Science and Urban Economics, Vol. 22, No. 1, pp. 123-132.

Gemeente Leiden (2014), Rapportage Parkeermonitor Leiden Juli - December 2013, Leiden, 5 March 2014, available online at http://www.leidenincijfers.nl/onderzoeksbank/1540-Parkeermonitor\%202013-2.pdf Gemeente Rotterdam (2010), Tarievenoverzicht Stadstoezicht 2010, downloadable at http://www.rotterdam.nl/STZ/Document/BenO/parkeertarieven\%202010/Tarievenoverzicht\%20Stadstoezic ht\%202010\%20versie\%203\%20mei\%202010.pdf

Gemeente Utrecht (2013), Nota Stallen en Parkern, February 2013.

Grooten, J. (J.Grooten@IVV.amsterdam.nl), 11 July 2014, Email to G. Mingardo (mingardo@ ese.eur.nl)

Guo, Z, and Ren, S. (2013), From Minimum to Maximum: Impact of the London Parking Reform on Residential Supply from 2004 to 2010?, Urban Studies, Vol. 50, No. 6, pp.1183-1200.

Ison, S. and Rye, T. (2006), Editorial: Parking, Transport Policy, Vol. 13, pp. 445-446.

Ison, S. and Rye, T. (2008), 'The implementation and Effectiveness of Transport Demand Management Measures', Ashgate, Aldershot, England.

Jakle, J.A. and Sculle, K.A. (2004), Lots of Parking: Land use in a car culture, University of Virginia Press, Charlottesville.

Kodransky, M. and Hermann, G. (2011), 'Europe's Parking U-Turn: from Accomodation to Regulation', Institute for Transportation and Development Policy, New York.

Lester, N. (Nick.Lester@londoncouncils.gov.uk), 27 November 2013. E-mail to G. Mingardo (mingardo@ese.eur.nl).

Levine, J. and Garb, Y. (2002), 'Congestion pricing's conditional promise: promotion of accessibility or mobility?', Transport Policy 9, pp. 179-188.

Ligocki, C. and Zonn, L. (1984), 'Parking problems in central business districts', Cities, Vol. 1, No. 4, pp. $350-355$.

Litman, T. (2006), Parking Management Best Practices, American Planning Association, Chicago, Illinois. London Borough of Camden (2007) Annual Parking Report. London Borough of Camden, London UK. Marsden, G. (2006), 'The evidence base for parking policies: a review', Transport Policy, Vol. 13, No. 6, pp. 447-457.

Meek, S., Ison, S. and Enoch, M. (2008) 'Role of Bus-based Park and Ride in the UK: a temporal and evaluative review', Transport Reviews, Vol. 28, no. 6, pp. 781-803. 
Meek, S., Ison, S. and Enoch, M. (2009) 'Stakeholder perspectives on the current and future roles of UK bus-based Park and Ride', Journal of Transport Geography, Vol. 17, no. 6, pp. 468-475.

Meek, S., Ison, S. and Enoch, M. (2010) 'UK local authority attitudes to Park and Ride', Journal of Transport Geography, Vol. 18, no. 3, pp. 372-381.

Meek, S., Ison, S. and Enoch, M. (2011) 'Evaluating alternative concepts of bus-based Park and Ride', Transport Policy, Vol. 18, no. 2, pp. 456-467.

Merriman, D. (1995), 'Subsidized Parking and Neighbourhood Nuisances', Journal of Urban Economics, Vol. 41, pp. 198-201.

Mingardo G, van den Berg L and van Haaren J (2008), Transport, Environment and Economy at urban level: the need for decoupling - A comparative study of four European cities: Rotterdam, London, Gothenburg and Hamburg, Rotterdam, EURICUR report 2/2008.

Mingardo G (2013) Transport and environmental effects of rail-based Park and Ride: evidence from the Netherlands, Journal of Transport Geography, Vol. 30, pp 7-16.

Moerkamp, J. (2013), 'Parkeren niet langer de melkkoe van de gemeenten', Binnenlands Bestuur, 13 October 2013.

Ommeren, J.N. van, D. Wentink and J. Dekkers (2011), The real price of parking policy, Journal of Urban Economics, Vol. 70, pp. 25-31.

Parkhurst, G. (2000), 'Influence of bus-based Park and Ride facilities on users' car traffic', Transport Policy, Vol. 7, no. 2, pp. 159-172.

Parkhurst, G. and Richardson, J. (2002), 'Modal integration of bus and car in UK local transport policy: the case for strategic environmental assessment', Journal of Transport Geography, Vol. 10, no. 1, pp. 195-206.

Pierce, G. and Shoup, D. (2013), 'Getting the price right', Journal of the American Planning Association, Vol. 79, No. 1, pp. 67-81.

Salomon, I. (1986), 'Towards a behavioural approach to city centre parking', Cities, Vol. 3, No. 3, pp. 200208.

Shoup, D. (1995), ‘An opportunity to reduce minimum parking requirements', Journal of the American Planning Association, Vol. 61, No. 1, pp. 14-28.

Shoup, D. (1997), 'Evaluating the effects of cashing out employer-paid parking: eight case studies', Transport Policy, Vol. 4, No. 4, pp. 201-216.

Shoup, D. (1999), 'The problem with minimum parking requirements', Transportation Research Part A: Policy and Practice, Vol. 33, No. 7-8, pp. 549-574.

Shoup, D. (2005), The High Cost of Free Parking, American Planning Association, Chicago, Illinois.

Shoup, D. (2013), On-Street Parking Management v. Off-Street Parking Requirements, Access, No. 42, pp. $38-40$. 
Small, K.A. (1997) 'Economics and urban transport policy in the United States', Regional Science and Urban Economics, Vol. 27, pp. 671-691.

Spark (2013), 'Gebruik binnenstedelijke parkeerplaatsen dealt 10\%’, press release, Leidschendam, november 2013 .

Stadsregio Rotterdam (2013), 'Parkeer en Reis verder met het openbaar vervoer', Factsheet P+R, June 2013, downloadable at http://stadsregio.nl/sites/stadsregio.nl/files/pagina-bestanden/Factsheet\%20P\%2BR.pdf Stumpel-Vos, P. and van de Vosse, W. (2012), Measure Evaluation Results - UTR 3.1 Innovation of the system of parking permits and rates, CIVITAS MIMOSA report, 9 November 2012;

Trillin, C. (2001) 'Tepper isn't going out', New York: Random House; quoted in Shoup, D. (2005), The High Cost of Free Parking, American Planning Association, Chicago, Illinois.

UK Department for Communities and Local Government (2012) National Planning Guidance. DCLG, London.

UK Department for Transport (DfT) (2006a) Delivering better local transport: Key Achievements and Good Practice from the First Round of Local Transport Plans. Produced for DfT, London, by Atkins, London.

UK Department for Transport (DfT) (2006b) Local Transport Plan 2 Guidance. DfT, London.

UK Department for Transport (DfT) (2007) Long Term Process and Impact Evaluation of the Local Transport Plan Policy, Final Report. Produced for DfT, London, by Atkins, London.

Van den Bergh, J. and Verhoef, E. (2001), Urban Transport Pricing in Amsterdam: policy simulation for 2005, in De Borger B. and Proost S (2001), Reforming Transport Pricing in the European Union - A modelling approach, Edward Elgar Publishing Limited, Cheltenham, UK.

Van Wee, B., J.A. Annema, D. Banister (Eds.) (2013), The transport system and transport policy. An introduction. Cheltenham, UK / Northampton, Massachusetts: Edward Elgar

Verhoef, E., Nijkamp, P. and Rietveld, P. (1995), 'The economics of regulatory parking policies: the (im)possibilities of parking policies in traffic regulation', Transportation Research A, Vol. 29A, No. 2, pp. 141-156.

Voith, R. (1997), 'Parking, Transit, and Employment in a Central Business District', Journal of Urban Economics, Vol. 44, pp. 43-58.

Voith, R. (1998) 'The Downtown Parking Syndrome: Does Curing the Illness Kill the Patient?', Business Review, Federal Reserve Bank of Philadelphia, January-February 1998.

White, J. (2008), 'The Greater London Council 1965 to 1986', chapter 5 in Kochan, J. 'London Government 50 Years of Debate', LSE London, November 2008. 


\section{Tables (not included in the main text)}

Table 1: Relationship between key elements and aims of parking policy and the stages of development.

\begin{tabular}{|c|c|c|c|c|c|c|c|}
\hline & & \multicolumn{3}{|c|}{ Phase 1: The rise of parking regulations } & \multicolumn{2}{|c|}{ Phase 2: the advent of parking pricing } & \multirow{2}{*}{$\begin{array}{l}\text { Phase 3: parking as integral part of TDM } \\
\text { strategies }\end{array}$} \\
\hline & & $\begin{array}{c}\text { Absence of parking } \\
\text { measures }\end{array}$ & $\begin{array}{l}\text { Parking regulations } \\
\text { and control }\end{array}$ & Time restriction & $\begin{array}{l}\text { Introduction of paid } \\
\text { parking }\end{array}$ & $\begin{array}{l}\text { Extension of paid } \\
\text { parking area }\end{array}$ & \\
\hline \multirow{2}{*}{$\stackrel{\text { E }}{\gtrless}$} & $\begin{array}{l}\text { Aim(s) of the } \\
\text { parking policy }\end{array}$ & - & $\begin{array}{l}\text { To regulate demand } \\
\text { and facilitate car } \\
\text { use }\end{array}$ & $\begin{array}{c}\text { To regulate } \\
\text { demand and } \\
\text { maximize the n. of } \\
\text { visitors }\end{array}$ & \multicolumn{2}{|c|}{$\begin{array}{l}\text { To regulate demand in order to keep car use } \\
\text { and traffic under control }\end{array}$} & $\begin{array}{l}\text { To improve the accessibility, the quality of life } \\
\text { and to support the economy of the city }\end{array}$ \\
\hline & $\begin{array}{l}\text { Major trends in } \\
\text { transport policy }\end{array}$ & \multicolumn{3}{|c|}{ "Predict \& Provide" } & \multicolumn{2}{|c|}{ "Command \& Control" } & "Managing demand" \\
\hline \multirow{4}{*}{$\stackrel{n}{8}$} & Requirements & $\begin{array}{l}\text { No parking } \\
\text { requirements }\end{array}$ & \multicolumn{2}{|c|}{$\begin{array}{l}\text { The first parking requirements are } \\
\text { introduced }\end{array}$} & \multicolumn{2}{|c|}{$\begin{array}{l}\text { Parking requirements are standard for all } \\
\text { kinds of new developments }\end{array}$} & $\begin{array}{l}\text { Minimum and maximum parking requirements are } \\
\text { introduced }\end{array}$ \\
\hline & Regulations & $\begin{array}{l}\text { No parking } \\
\text { regulations; cars can } \\
\text { park everywhere }\end{array}$ & $\begin{array}{l}\text { Parking spaces are } \\
\text { clearly marked } \\
\text { In some areas it is } \\
\text { prohibited to park }\end{array}$ & $\begin{array}{l}\text { Introduction of } \\
\text { time restrictions }\end{array}$ & $\begin{array}{l}\text { Introduction of } \\
\text { pricing parking in the } \\
\text { central area together } \\
\text { with residents } \\
\text { permits }\end{array}$ & $\begin{array}{l}\text { Extension of the } \\
\text { pricing parking area }\end{array}$ & $\begin{array}{c}\text { Further extension of pricing area } \\
\text { Use of differentiated parking fees } \\
\text { Park \& Ride facilities } \\
\text { Multiple use of parking facilities } \\
\text { Workplace Parking Levies }\end{array}$ \\
\hline & Marketing & - & - & - & \multicolumn{2}{|c|}{$\begin{array}{l}\text { Some promotion of specific off-street } \\
\text { facilities might be done in attempt to increase } \\
\text { use of underutilized supply }\end{array}$} & $\begin{array}{c}\text { Promotion of } P \& R \text { facilities to encourage people } \\
\text { not to enter the city center by car } \\
\text { Promotion of multiple use of parking facilities }\end{array}$ \\
\hline & $\begin{array}{l}\text { Information \& } \\
\text { Communication }\end{array}$ & - & \multicolumn{2}{|c|}{$\begin{array}{l}\text { Simple information about how the } \\
\text { parking system works }\end{array}$} & \multicolumn{2}{|c|}{$\begin{array}{l}\text { Simple information about how the parking } \\
\text { system works } \\
\text { Appearance of the first information systems, } \\
\text { such as digital boarding indicating the } \\
\text { number of available spaces in off-street } \\
\text { facilites }\end{array}$} & $\begin{array}{l}\text { Massive use of IT to guide people to available } \\
\text { parking and avoid unnecessary cruising }\end{array}$ \\
\hline
\end{tabular}


